\title{
Erratum to: Predicting the functions of a protein from its ability to associate with other molecules
}

Kamal Taha ${ }^{1 *}$ and Paul D. Yoo ${ }^{2}$

Upon publication of the original article [1] it was found that author corrections for Table 1 were not correctly implemented. You can now find the correct Table 1 below and also updated in the original article.

Table 1 The distribution of semantically related and semantically unrelated co-occurrences of molecule $m_{i}$ and Protein $p$ Pair in an Abstract $A_{j}$

\begin{tabular}{llll}
\hline$m_{i}$ and $p$ co-occur in the same sentence & Yes & No & Total \\
$m_{i}$ and $p$ are semantically related & & & \\
\hline Yes & $O_{11}$ & $O_{12}$ & $R_{1}$ \\
No & $O_{21}$ & $O_{22}$ & $R_{2}$ \\
Total & $C_{1}$ & $C_{2}$ & $N$ \\
\hline
\end{tabular}

\section{Author details}

${ }^{1}$ Department of Electrical and Computer Engineering, Khalifa University, Abu Dhabi, United Arab Emirates. ${ }^{2}$ Faculty of Science and Technology,

Bournemouth University, Bournemouth, UK.

Published: 26 February 2016

\section{References}

1. Taha K, Yoo PD. Predicting the functions of a protein from its ability to associate with other molecules. BMC Bioinformatics. 2016;17:34.

\footnotetext{
* Correspondence: kamal.taha@kustar.ac.ae

'Department of Electrical and Computer Engineering, Khalifa University, Abu Dhabi, United Arab Emirates
}

Submit your next manuscript to BioMed Central and we will help you at every step:

- We accept pre-submission inquiries

- Our selector tool helps you to find the most relevant journal

- We provide round the clock customer support

- Convenient online submission

- Thorough peer review

- Inclusion in PubMed and all major indexing services

- Maximum visibility for your research

Submit your manuscript at www.biomedcentral.com/submit
() Biomed Central

\section{Biomed Central}

(c) 2016 Taha and Yoo. Open Access This article is distributed under the terms of the Creative Commons Attribution 4.0 International License (http://creativecommons.org/licenses/by/4.0/), which permits unrestricted use, distribution, and reproduction in any medium, provided you give appropriate credit to the original author(s) and the source, provide a link to the Creative Commons license, and indicate if changes were made. The Creative Commons Public Domain Dedication waiver (http://creativecommons.org/publicdomain/zero/1.0/) applies to the data made available in this article, unless otherwise stated. 